\title{
Eruca sativa L-A promising source of drug lead for antimicrobial, neuroprotective and anticancer treatment regimens: Pharmacological properties of medicinal plant "Eruca sativa"
}

\author{
Waseem Mohammed Abdul ${ }^{\mathrm{a}}$, Syed Shoeb Razvi ${ }^{*}$
}

\author{
${ }^{a}$ MS Research Foundation, Masab Tank, Hyderabad, India. \\ Received: 03 May 2019 / Revised: 27 June 2019 / Accepted: 30 June 2019
}

\begin{abstract}
Rocket (Eruca sativa) is a low-calorie leafy vegetable of the family Brassicaceae under the genera Eruca mostly consumed raw in salads. It has been used since ancient times from food to medicine and cosmetics without any knowledge of the mechanism or the targets involved. However, presently, the production and cultivation of rocket have significantly increased owing to its different biological effects. Erucin and Sulforaphane are the most commonly studied isothiocyanates obtained from the plant parts of Eruca sativa. Over time, with continuous usage of conventional and synthetic drugs, the drug resistant and off-target toxicities rapidly increase, which necessitates for alternative medicine with increased specificity and minimal detrimental effects. It is interesting to note that many previous studies have reported the antimicrobial impact of E. sativa against the pathogenic bacterial species like Escherichia coli, Staphylococcus aureus, Salmonella typhimurium, etc. Moreover, Erucin obtained from E. sativa has shown significant inhibitory and protective effect against different human cancer cell lines and xenograft animal models. The present review gives a brief overview of the antimicrobial, neuroprotective and anticancer effects of the various plant parts of $E$. sativa and the most bioactive isothiocyanates. It is exciting to note that epigenetic modulation of gene expression has also been reported in some studies which could be a new direction of research on the path of naturopathy.
\end{abstract}

Keywords: Eruca sativa, Erucin, Anticancer, Isothiocyanate, Antimicrobial, Molecular targets.

(C) Euraass 2019. All rights reserved.

\section{Introduction}

Cruciferous vegetables have attracted the attention of the researchers globally to explore the active biomolecules like isothiocyanates, polyphenols and flavonoids with antimicrobial, anticancer, anti-inflammatory, antidiabetic and neuroprotective effects [1]-[5]. "Rocket" refers to the leafy green vegetables of the genera Eruca classified under the family Brassicaceae [6]. Besides being rich in fibre, different plant parts of Eruca are rich in bioactive molecules like polyphenols, flavonoids, glucosinolates and nitrate content with proven pharmaceutical and anticancer properties. Eruca sativa L. (salad rocket, Figure 1) is the most commonly used species for human consumption in South Asia, Middle East and Europe [7], [8].

The leaves have a strong flavour with the pungent smell, but the species differ in the size of the leaves, the colour of the flowers and the content of the isothiocyanates and glucosinolates [9].

Natural plant products and naturopathy is an emerging field for alternative medicine which gives a glimmer of hope to the

* Corresponding author. E-mail address: shoebiqbal@outlook.com (S.S Razvi), Phone: 00917995709100

Available online: 30 June 2019

DOI: https://doi.org/10.34154/2019-EJCS-0101-17-21/euraass

Cite this: Eur. J. Cell Sci. 2019, 1(1), 17 - 21.

ISSN-E: 2679-3350.

(C) European Academy of Applied and Social Sciences. Euraass - 2019. All rights reserved. 
researchers to prevent or treat the life-threatening diseases and disorders. We have described briefly and highlighted the significant antimicrobial, neuroprotective and anticancer effects of the plant parts of E. sativa.

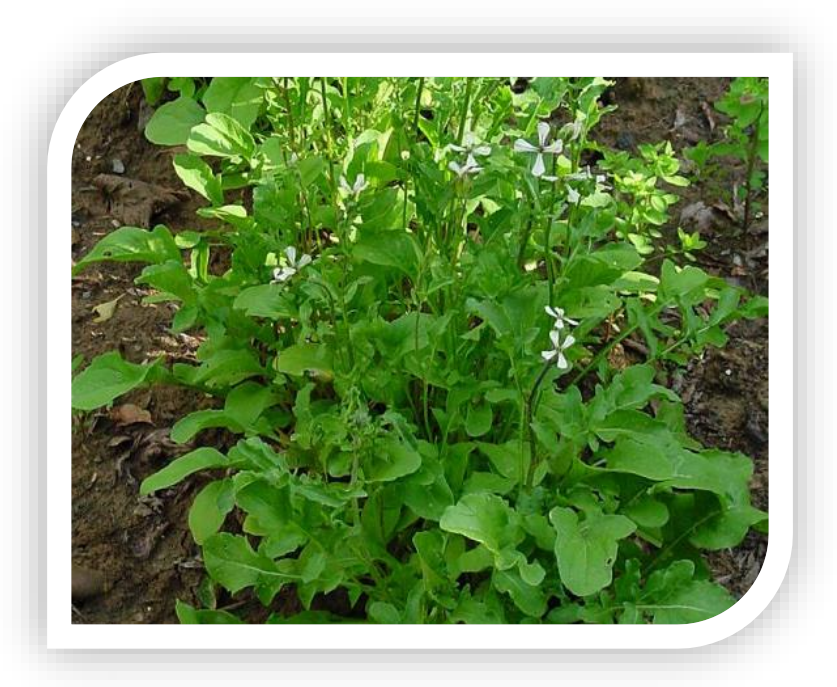

Figure 1: The foliage of cruciferous vegetable Eruca sativa $\mathrm{L}$.

\section{Antimicrobial activity}

In a study by kauba et al. 2015, Eruca sativa ethanol extract was used to evaluate the antimicrobial effects of both gram positive and gram negative pathogenic strains. All the tested strains of bacteria have shown a significant zone of inhibition at $7 \mathrm{mg} / \mathrm{ml}$ and 14 $\mathrm{mg} / \mathrm{ml}$ concentrations. The highest zone of inhibition of $16.7 \mathrm{~mm}$ was observed in Salmonella typhimurium followed by Bacillus subtilis with a zone of inhibition as $16.6 \mathrm{~mm}$ at a concentration of $14 \mathrm{mg} / \mathrm{ml}$. On the other hand, Escherichia coli have shown the zone of inhibition of $16.0 \mathrm{~mm}$ and Bacillus thuringensis as $15.6 \mathrm{~mm}$ at a concentration of $14 \mathrm{mg} / \mathrm{ml}$ [10].

In another study, antimicrobial activity of $E$. sativa was screened against three-gram negative bacteria, Escherichia coli, Staphylococcus flexneri and Pseudomonas aeruginosa and twogram positive bacteria Bacillus subtilis and Staphylococcus aureus. Extracts from both aerial and root parts were used against different bacteria, and almost all the extracts exhibited antimicrobial activity. The seed oil has shown maximum zone of inhibition (97\%) for gram-positive bacteria compared to gram-negative bacteria. The extract has shown activity equal to standard broad-spectrum
Table 1: Outline of the inhibitory effect of Eruca sativa extracts on some of the pathogenic bacteria in the documented literature.

\begin{tabular}{|c|c|c|c|c|}
\hline $\begin{array}{l}\text { Bacterial } \\
\text { species }\end{array}$ & $\begin{array}{l}\text { E. sativa } \\
\text { extract }\end{array}$ & $\begin{array}{c}\text { Concentratio } \\
n\end{array}$ & $\begin{array}{c}\text { Zone of } \\
\text { inhibitio } \\
n(\mathrm{~mm})\end{array}$ & $\begin{array}{c}\text { Refe } \\
\text { renc } \\
\text { e }\end{array}$ \\
\hline $\begin{array}{l}\text { Salmonella } \\
\text { typhimurium }\end{array}$ & Ethanolic & $14 \mathrm{mg} / \mathrm{ml}$ & 16.7 & [10] \\
\hline $\begin{array}{l}\text { Bacillus } \\
\text { subtilis }\end{array}$ & Ethanolic & $14 \mathrm{~g} / \mathrm{ml}$ & 16.6 & [10] \\
\hline $\begin{array}{l}\text { Staphylococ } \\
\text { cus aureus }\end{array}$ & Seed oil & $30 \mu \mathrm{g} / \mathrm{ml}$ & $\begin{array}{c}30.67 \pm \\
2.52\end{array}$ & [11] \\
\hline B. subtilis & Seed oil & $30 \mu \mathrm{g} / \mathrm{ml}$ & $\begin{array}{c}24.33 \pm \\
1.16\end{array}$ & [11] \\
\hline $\begin{array}{l}\text { Escherichia } \\
\text { coli }\end{array}$ & Aqueous & $20 \mu \mathrm{l}$ & 19 & [4] \\
\hline S.aureus & Aqueous & $20 \mu \mathrm{l}$ & 12 & [4] \\
\hline $\begin{array}{l}\text { Escherichia } \\
\text { coli }\end{array}$ & $\begin{array}{l}\text { Ethyl } \\
\text { acetate }\end{array}$ & $20 \mu \mathrm{l}$ & - & [4] \\
\hline S.aureus & $\begin{array}{l}\text { Ethyl } \\
\text { acetate }\end{array}$ & $20 \mu \mathrm{l}$ & - & [4] \\
\hline S.aureus & $\begin{array}{l}\text { Ethyl } \\
\text { acetate }\end{array}$ & $0.8 \mathrm{mg} / \mathrm{ml}$ & $\begin{array}{c}25.66 \pm 0 . \\
57\end{array}$ & [2] \\
\hline S.aureus & chloroform & $0.8 \mathrm{mg} / \mathrm{ml}$ & $\begin{array}{l}23.16 \\
\pm 0.76\end{array}$ & [2] \\
\hline S.aureus & Ethanol & $0.8 \mathrm{mg} / \mathrm{ml}$ & $\begin{array}{c}14.33 \pm 2 . \\
08\end{array}$ & [2] \\
\hline S.aureus & Methanol & $0.8 \mathrm{mg} / \mathrm{ml}$ & $\begin{array}{c}16.00 \pm 1 \\
00\end{array}$ & [2] \\
\hline
\end{tabular}

antibiotic ciprofloxacin [11].

Qaddoumi et al. have tested the antimicrobial activity of ethyl acetate and water extract of E.sativa against Escherichia coli and Staphylococcus aureus and there was a significant inhibition in both of the bacterial species. The zone of inhibition of Escherichia coli was $19 \mathrm{~mm}$, and for S.aureus, it was $12 \mathrm{~mm}$ when tested with water extract. The ethyl acetate extract has shown no antimicrobial activity against Staphylococcus aureus, Callus cereus and Escherichia coli [4].

In one study by Rizwana et al. the antibacterial activity of five different types of extracts of E. sativa such as chloroform, acetone, ethyl acetate, ethanol and methanol was evaluated against both gram-negative and gram-positive bacteria. The results were significant, and the extracts have found to inhibit the test organisms. The maximum zone of inhibition was observed against S.aureus with ethyl acetate and chloroform extracts $(25.66 \pm 0.57$, $23.16 \pm 0.76$ ) respectively followed by methanol and ethanol $(16.00 \pm 1.00,14.33 \pm 2.08)$ respectively [2]. Table 1 depicts an overview of the antimicrobial activity exhibited by Eruca sativa extract on some of the resistant bacterial species. 


\section{Neuroprotective and Anti-inflammatory activity}

Eruca sativa seed extract (ESE) was used to test the neuroprotective anti-inflammatory effects in NSC-34 motor neurons exposed to the medium of LPS- treated RAW 264.7. After the confirmation of inflammation in macrophages, the ESE was evaluated to check its ability to counteract the inflammation induced in NSC-34. At first, the ESE was used to assess the morphological changes or cytotoxicity in NSC-34 at concentrations $0.1,0.2$ and $0.3 \mu \mathrm{g} / \mathrm{ml}$. There was no cytotoxicity till $0.3 \mu \mathrm{g} / \mathrm{ml}$, but the highest concentration (i.e., $0.4 \mu \mathrm{g} / \mathrm{ml}$ ) have shown moderate cytotoxicity [12].

The morphological changes were evaluated and by Eosin/hematoxylin staining. After treatment with ESE, there was cell death, and degeneration was observed in NSC-34 motor neurons exposed to the medium of LPS-treated RAW 264.7. The ESE concentration of $0.3 \mu \mathrm{g} / \mathrm{ml}$ was found to be most effective. After the treatment of NSC-34 motor neurons LPS-stimulated RAW 264.7, induced apoptosis associated with FasL-positive staining [12].

\section{Anticancer effect}

There is considerable literature on the reduced risk of the development of different types of cancers with the regular consumption of cruciferous vegetables of the Rocket, Eruca sativa L. This anticancer effect is attributed to the isothiocyanates, which is a hydrolysis product obtained from these vegetables. Erucin (ER) obtained from rocket salads is structurally related to the isothiocyanate-sulforaphane. Many previous in vitro and in vivo studies have reported the promising anticancer effect of the ER.

The protective effect of ER against cancer was shown by a research group for the first time in different mouse tissues mediated through the induction of multiple detoxification enzymes. However, later, the anticancer effect of ER was subsequently confirmed in many human cancer cells. Various studies have reported the anticancer effect of ER in a panel of human cancer cell lines like liver, colon, lung and prostate through different mechanisms like apoptosis, cell cycle regulation, inhibition of proliferation and mitochondrial depolarisation. In an interesting study, it was reported that ER-induced apoptosis and cell cycle arrest in human leukaemia cells, including the multidrug-resistant variants.

In a study by fimognari et al. ER exhibited a selective, strong antiproliferative effect on human leukaemia cells, but there was no effect on the non-transformed peripheral $T$ lymphocytes. Thus, it is evident that the ER is a natural ITC with a selective inhibitory effect on human cancer cells. Previous literature has reported the similar biological effects of ER and sulforaphane [13]-[17], but however, sulforaphane showed the anticancer effect on both transformed and non-transformed human leukaemia cells [18]. Moreover, the selectivity of ER is also evident from a previous preclinical study wherein the liver cancer cell with differentiated p53 status were tested, and ER showed selective inhibition of tumour cells by targeting even chemoresistant cancer-initiating cells [19]. This selectivity of ITC is an exciting area of research which needs to be explored further to translate the findings of the laboratory to the actual clinical settings if the exact mechanisms are unveiled. Interestingly, there might be some harmful effects of the benzyl or phenethyl isothiocyanates, but this has not been reported for other isothiocyanates such as ER or sulforaphane.

Additionally, reactive oxygen species (ROS) also plays a vital role in cancer prevention and cell death through signal transduction. It has been reported by Wang and colleagues that ER is a potent inducer of thioredoxin reductase 1 , which can reduce lipid hydroperoxides and hydrogen peroxides in MCF7 due to its broad substrate specificity. Thus ITCs may modulate the redox status of the cells by exerting indirect antioxidant activity through ROS [20].

Another study by Melchini and colleagues reported the anticancer effect of ER in human lung carcinoma A549 cells [1]. It was demonstrated that ER exhibited the anticancer effect in A549 cells through the induction of apoptosis by upregulation of p53 and p21 and enhancing the expression of PARP-1 cleavage consequently leading to cell cycle arrest [1].

A 36 week in vivo study on the rats fed with a diet of $160 \mu \mathrm{mol}$ kg-1 bw d-1 broccoli sprout extract and administered with a specific bladder carcinogen, $0.05 \%$ N-butyl-N-(4-hydroxybutyl) nitrosamine (BBN), demonstrated a significant reduction in the size, multiplicity, incidence, and progression of bladder cancer [21]. A recent review has elaborated the animal, and preclinical studies and the prevention of bladder cancer with different isothiocyanates, including ER obtained from different cruciferous vegetables [22].

In another in vivo study in a murine UMUC3 xenograft model, it was reported that the animals fed on ER at $295 \mu \mathrm{mol} / \mathrm{kg}$, exhibited a significant reduction in the tumour weight by $58 \%(p<0.0001)$, with induction of apoptosis as evidenced with an increased expression of PARP cleavage [23]. Interestingly, ER also inhibited HDACs 1, 2, 4 and 6 in in vitro human bladder cancer cells and in invasive in vivo xenografts models [16]. Therefore, epigenetic modulation can be achieved in future as a preventive strategy by ER-mediated targeting of histones. The ongoing discussion gives a novel direction of approach to explore the intermediate biomarkers for food-based clinical interventions in extensive group studies. Figure 2 provides a brief overview of the molecular targets of ER reported in different cell lines. 


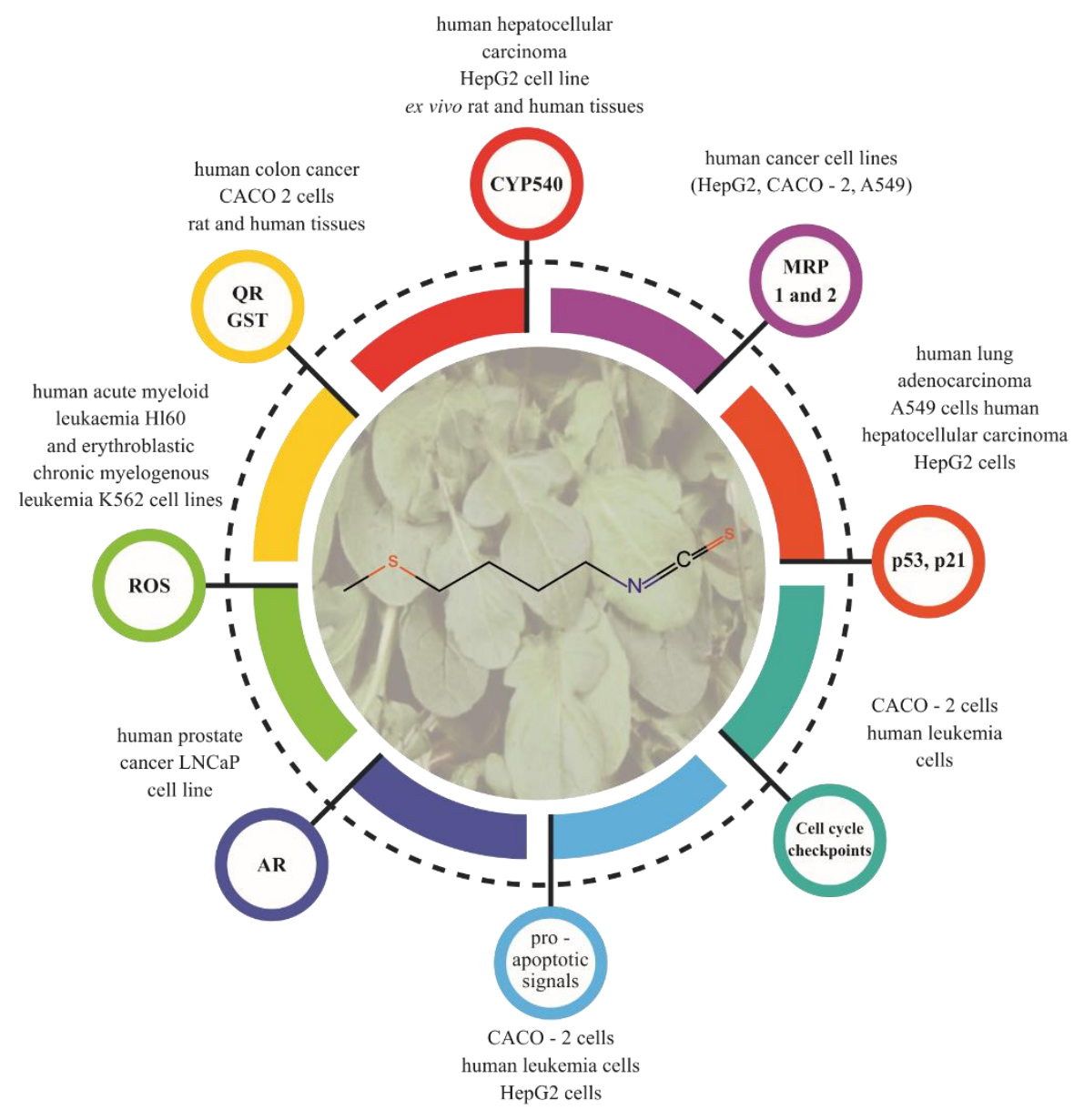

Figure 2: Overview of the molecular targets of erucin, a bioactive isothiocyanate from Eruca sativa L. in different in vitro and in vivo anticancer studies as reported from the previous studies [6]. QR-Quinone reductase; GST-Glutathione Transferase; MRP-Multidrug resistance protein; AR-Androgen Receptor; ROS-Reactive Oxygen Species.

\section{Conclusion}

The most common challenges with the bioactive phytochemicals is the decreased bioavailability and low retention in blood-plasma levels. However, this could be solved with the latest and innovative technological improvements to alter the surface of the biomolecules, which may increase the bioavailability and also the specificity. Moreover, with the application of -omics approach, the gene and protein-based studies could be performed on the bioactive phytochemicals of Eruca, which will open novel therapeutic avenues to treat different cancers and pathogenic microbes. The baseline is there should be an effective translation from the research laboratory to the clinical setting to address the challenges in treatment.

\section{Conflicts of Interest}

The authors declare that they have no financial conflict of interest.

\section{Author Contributions}

WA and SR analysed the data, performed literature review and wrote the paper.

\section{References}

1. A. Melchini et al. (2009) "Erucin, a new promising cancer chemopreventive agent from rocket salads, shows antiproliferative activity on human lung carcinoma A549 cells.," Food Chem. Toxicol., vol. 47, no. 7, pp. 1430-1436

2. H. Rizwana, S. Mona, Alwhibi.S, F.Khan, and D. Soliman (2016) "Chemical composition and antimicrobial activity of 
Eruca sativa seeds against pathogenic bacteria and fungi.," vol. 26, no. 6, pp. 1859-1871.

3. L. Bell, L. Methven, A. Signore, and M. J. Oruna-concha (2016) "Analysis of Seven Salad Rocket (Eruca sativa) Accessions: The Relationships Between Sensory Attributes and Volatile and Non-volatile Compounds," Food Chem.

4. S. Qaddoumi and N. El-banna (2019) "Antimicrobial Activity of Arugula ( Eruca Sativa) Leaves on Some Pathogenic Bacteria," Int. J. Biol., vol. 11, no. 3, pp. 10-15.

5. M. S. Ciprés, I. Boschiero, and S. D. Acqua (2014) "Extraction of bioactive enriched fractions from Eruca sativa leaves by supercritical CO2 technology using ...," J. Supercrit. Fluids, vol. 94, no. October, pp. 245-251.

6. A. Melchini and M. H. Traka (2010) "Biological profile of erucin: a new promising anticancer agent from cruciferous vegetables.," Toxins (Basel)., vol. 2, no. 4, pp. 593-612.

7. P. Bogani and F. Visioli (2007) "Antioxidants in the Mediterranean Diets: An Update," in World Review of Nutrition and Dietetics, vol. 97, pp. 162-179.

8. S. Schaffer, S. Schmitt-Schillig, W. E. Muller, and G. P. Eckert (2015) "Antioxidant properties of Mediterranean food plant extracts: geographical differences.," J. Physiol. Pharmacol., vol. 56 Suppl 1, pp. 115-124.

9. M. Cavaiuolo and A. Ferrante (2014) "Nitrates and glucosinolates as strong determinants of the nutritional quality in rocket leafy salads," Nutrients, vol. 6, no. 4, pp. 1519-1538.

10. M. Koubaa, D. Driss, B. Fatma, R. Ghorbel, and S. Chaabouni (2015) "Antioxidant and antimicrobial activities of solvent extract obtained from rocket (Eruca sativa L .) flowers.," Free Radic. Antioxidants, vol. 5, no. 1, pp. 20-22.

11. M. Khoobchandani et al (2010) "Antimicrobial properties and analytical profile of traditional Eruca sativa seed oil : Comparison with various aerial and root plant extracts," Food Chem., vol. 120, no. 1, pp. 217-224.

12. A. Gugliandolo, S. Giacoppo, M. Ficicchia, A. Aliquò, P. Bramanti, and E. Mazzon (2018) "Eruca sativa seed extract: A novel natural product able to counteract neuroinflammation," Mol. Med. Rep., vol. 17, pp. 6235-6244.

13. N. Hanlon, N. Coldham, M. J. Sauer, and C. Ioannides (2009) "Modulation of rat pulmonary carcinogen-metabolising enzyme systems by the isothiocyanates erucin and sulforaphane.," Chem. Biol. Interact., vol. 177, no. 2, pp. 115-120.
14. N. Hanlon, C. L. Poynton, N. Coldham, M. J. Sauer, and C. loannides (2009) "The aliphatic isothiocyanates erucin and sulforaphane do not effectively up-regulate $\mathrm{NAD}(\mathrm{P}) \mathrm{H}$ :quinone oxidoreductase (NQO1) in human liver compared with rat," Mol. Nutr. Food Res., vol. 53, no. 7, pp. 836-844.

15. J. Barillari et al. (2005) "Direct Antioxidant Activity of Purified Glucoerucin, the Dietary Secondary Metabolite Contained in Rocket (Eruca sativa Mill.) Seeds and Sprouts," J. Agric. Food Chem., vol. 53, no. 7, pp. 2475-2482.

16. B. Abbaoui et al. (2017) "The impact of cruciferous vegetable isothiocyanates on histone acetylation and histone phosphorylation in bladder cancer.," J. Proteomics, vol. 156, pp. 94-103.

17. B. Abbaoui, C. R. Lucas, K. M. Riedl, S. K. Clinton, and A Mortazavi (2018) "Cruciferous Vegetables, Isothiocyanates, and Bladder Cancer Prevention," Mol. Nutr. Food Res., vol. 62, no. 18, p. 1800079.

18. C. Fimognari, M. Nusse, F. Berti, R. Iori, G. Cantelli-Forti, and P. Hrelia (2003) "Sulforaphane modulates cell cycle and apoptosis in transformed and non-transformed human $\mathrm{T}$ lymphocytes.," Ann. N. Y. Acad. Sci., vol. 1010, pp. 393-398.

19. E. Lamy et al. (2013) "Preclinical Evaluation of 4Methylthiobutyl Isothiocyanate on Liver Cancer and Cancer Stem Cells with Different p53 Status," PLoS One, vol. 8, no. 8, p. e70846.

20. W. Wang, S. Wang, A. F. Howie, G. J. Beckett, R. Mithen, and Y. Bao (2005) "Sulforaphane, erucin, and iberin up-regulate thioredoxin reductase 1 expression in human MCF-7 cells.," J. Agric. Food Chem., vol. 53, no. 5, pp. 1417-1421.

21. R. Munday et al. (2008) "Inhibition of urinary bladder carcinogenesis by broccoli sprouts.," Cancer Res., vol. 68, no. 5, pp. 1593-1600.

22. O. L. Veeranki, A. Bhattacharya, L. Tang, J. R. Marshall, and $Y$. Zhang (2015) "Cruciferous vegetables, isothiocyanates, and prevention of bladder cancer.," Curr. Pharmacol. reports, vol. 1, no. 4, pp. 272-282.

23. B. Abbaoui et al. (2012) "Inhibition of bladder cancer by broccoli isothiocyanates sulforaphane and erucin characterization, metabolism, and interconversion.," Mol. Nutr. Food Res., vol. 56, no. 11, pp. 1675-1687. 